\title{
A CHRONOLOGICAL GUIDE TO INTERNATIONAL RADIOCARBON CONFERENCES AND PUBLICATIONS
}

1. Godwin, H. 1954 1st Carbon-14 Dating Symposium. Copenhagen, 1-4 September. Nature 174: 868.

2. Levi, H. 1955 2nd Radiocarbon Dating Conference. Cambridge, 25-30 July. Nature 176: 727728.

3. Johnson, F., Arnold, J. and Flint, R. F. 1957 3rd International Conference on Radiocarbon Dating. Andover, Massachusetts, 1-4 October. Science 125: 240.

4. Godwin, H. 1959 4th Carbon-Dating Conference. Groningen, 14-19 September. Nature 184: 1356-1366.

5. Godwin, H. 1962 5th Radiocarbon Dating Conference. Cambridge, 23-28 July. Nature 195(4845): 943-945.

6. Chatters, R. M. and Olson, E. A., eds. 19656 th International Conference on Radiocarbon and Tritium Dating. Pullman, Washington. Clearinghouse for Federal Scientific and Technical Information, National Bureau of Standards, U.S. Department of Commerce, Washington, DC.

7. Olsson, I. U., ed. 1970 Radiocarbon Variations and Absolute Chronology. Proceedings of the 12th Nobel Symposium and 7th International Radiocarbon Conference, Uppsala University, 1969. Stockholm, Almqvist \& Wiksell and New York, John Wiley \& Sons.

8. Rafter, T. A. and Grant-Taylor, T., eds. 1973 Proceedings of the 8th International Conference on Radiocarbon Dating. Lower Hutt, New Zealand, 1972. Wellington, New Zealand, Royal Society of New Zealand.

9. Berger, R. and Suess, H. E., eds. 1979 Radiocarbon Dating, Proceedings of the 9th International ${ }^{14} \mathrm{C}$ Conference. La Jolla/San Diego, California, 1976. Berkeley, University of California Press.

10. Stuiver, M. and Kra, R. S., eds. 1980 Proceedings of the 10 th International ${ }^{14} \mathrm{C}$ Conference. Bern/Heidelberg, 19-26 August 1979. Radiocarbon 22(2-3): 131-1016.

11. Stuiver, M. and Kra, R. S., eds. 1983 Proceedings of the 11 th International ${ }^{14} \mathrm{C}$ Conference. Seattle, Washington, 21-26 June 1982. Radiocarbon 25(2): 171-796.

12. Stuiver, M. and Kra, R. S., eds. 1986 Proceedings of the 12 th International ${ }^{14} \mathrm{C}$ Conference. Trondheim, Norway, 24-28 June 1985. Radiocarbon 28(2A): 175-804.

13. Long, A., Kra, R. S. and Srdoc, D., eds. 1989 Proceedings of the 13 th International ${ }^{14} \mathrm{C}$ Conference. Dubrovnik, Yugoslavia, 20-25 June 1988. Radiocarbon 31(3): 229-1082.

14. Long, A. and Kra, R.S., eds. 1992 Proceedings of the 14 th International ${ }^{14} \mathrm{C}$ Conference. Tucson, Arizona, 20-24 May 1991. Radiocarbon 34(3): 277-942.

15. Cook, G. T., Harkness, D. D., Miller, B. F. and Scott, E. M., eds. 1995 Proceedings of the 15 th International ${ }^{14} \mathrm{C}$ Conference. Glasgow, Scotland, 15-19 August 1994. Radiocarbon 37(2): 89844. 